\title{
Dynamics and vertical distribution of a Hrabeiella periglandulata (Annelida) population in South Moravia, Czech Republic
}

\author{
Jiří Schlaghamerský(1) and Adéla Šídová(1) \\ (1)Masaryk University, Faculty of Science, Department of Botany and Zoology, Kotlářská 2, CZ-611 37 Brno, Czech Republic. \\ E-mail: jiris@sci.muni.cz
}

\begin{abstract}
The objective of this work was to evaluate the density, dynamics and vertical distribution of a Hrabeiella periglandulata population in a forest soil at Brno, Czech Republic. From December 2003 to November 2004, two plots covered by mixed stands and two covered by coniferous stands were sampled monthly. Six soil cores per plot were taken down to $15 \mathrm{~cm}$ and subdivided into layers, which were subjected to wet funnel extraction. Missing in one of the coniferous stands $H$. periglandulata was abundant in the mixed stand with the highest soil $\mathrm{pH}$. In this stand, monthly sampling continued until November 2005, with three additional samplings up to January 2007 . Mean annual density was $2,672 \pm 1,534$ individuals $\mathrm{m}^{-2}$. Population dynamics differed from those reported from Germany. Highest densities were reached in early summer, lowest between August and December. Due to aggregated horizontal distribution, differences between monthly values were often nonsignificant. No significant correlation with climatic data was found. Nevertheless, the observed dynamics corresponded to the climatic conditions, showing particularly the negative effect of drought. The population was evenly distributed in the sampled soil profile, only avoiding the organic layer. Except for a locality in Poland, this is the easternmost record of the species.
\end{abstract}

Index terms: soil biology, soil fauna, terrestrial Polychaeta.

\section{Dinâmica e distribuição vertical de uma população de Hrabeiella periglandulata (Annelida) no Sul da Morávia, República Tcheca}

Resumo - O objetivo deste trabalho foi avaliar a densidade, a dinâmica e a distribuição vertical de uma população de Hrabeiella periglandulata em uma floresta de Brno, República Tcheca. De dezembro de 2003 a novembro de 2004, amostras de solo foram coletadas mensalmente, em duas áreas de floresta mista e duas áreas de floresta de coníferas. Em cada área, seis amostras de solo foram retiradas até a profundidade de $15 \mathrm{~cm}$, subdivididas em camadas e colocadas para extração úmida em funil. Não encontrada em uma das áreas de floresta de coníferas, H. periglandulata foi abundante na área de floresta mista com $\mathrm{pH}$ do solo mais alto, onde a amostragem mensal continuou até novembro de 2005, com três amostragens adicionais até janeiro de 2007. A densidade média anual foi de $2.672 \pm 1.534$ indivíduos por $\mathrm{m}^{2}$. A dinâmica populacional diferiu da encontrada na Alemanha. As maiores densidades foram encontradas no início do verão, e as menores entre agosto e dezembro. Em razão da distribuição horizontal agregada, diferenças entre os valores mensais foram, frequentemente, não significativas. Nenhuma correlação significativa com dados climáticos foi encontrada. No entanto, as dinâmicas observadas corresponderam às condições climáticas, particularmente, ao efeito negativo da seca. A população foi homogeneamente distribuída no perfil de solo amostrado, e evitou, somente, a camada orgânica. Com exceção de uma localidade na Polônia, este é o registro mais a leste sobre esta espécie.

Termos para indexação: biologia do solo, fauna edáfica, Polychaeta terrestre.

\section{Introduction}

Hrabeiella periglandulata Pižl \& Chalupský, 1984, is one of the two truly soil-dwelling, non-clitellate annelids ("Polychaeta") known so far. Since its description (Pižl \& Chalupský, 1984), its unclear systematic position has provoked several studies on morphology and phylogeny (Rota \& Lupetti, 1996, 1997; Rota, 1998; Purschke, 1999; Purschke, 2000; Rota et al., 2001; Purschke, 2003; Jördens et al.,
2004). Whereas a formerly proposed close relationship to the other truly soil-dwelling, polychaetous annelid Parergodrilus heideri Reisinger, 1925, has been repeatedly dismissed, some morphological and, in particular, ultrastructural characters suggest a potential sister-group relationship with the Clitellata. However, mollecular analyses have so far not supported this view.

Little is known about its ecology and area of distribution. In all cases, the species has been recorded 
in studies focusing on enchytraeids. Records have been published from Europe only, showing a range from southern Sweden in the north (Erséus \& Rota, 1998), across central Europe - Germany (Jans \& Römbke, 1989; Graefe, 1989, 1990, 1993a, 1993b; Purschke, 1999; Beylich \& Graefe, 2007), Czechia (Pižl \& Chalupský, 1984; Š́́dová \& Schlaghamerský, 2007) and Poland (Dumnicka \& Rożen, 2002) - to central Italy in the South (Rota \& Lupetti, 1996). It has been found in soils of deciduous and coniferous forests, as well as of meadows and gardens. Graefe \& Schmelz (1999) have characterised the species as an indicator of fresh soils (absent in wet habitats) of slight to moderate soil acidity (adapted to acidity stress), and preferring the $\mathrm{A}_{\mathrm{h}}$-horizon of soils with mull to moder humus forms. According to Rota (1998), the species cannot endure a prolonged submersion in water, but is also very sensitive to drought.

This work reports on a population found in a municipal forest of the city of Brno (South Moravia, southeastern Czech Republic), during a study on enchytraeids (Clitellata: Enchytraeidae) commenced in late 2003 (Schlaghamerský \& Š́́dová, 2007; Šídová \& Schlaghamerský, 2007). Comparable ecological data on $H$. periglandulata have only been published from a few sites in southwestern Germany (Jans \& Römbke, 1989), but even in that study, no proper year-round sampling was conducted.

The objective of the present study is to provide information on the density, population dynamics and vertical distribution of this population of $H$. periglandulata, based on year-round data.

\section{Materials and Methods}

The study was conducted in the Holedná Game Park and in an adjacent forest $\left(49^{\circ} 12^{\prime} \mathrm{N}, 16^{\circ} 32^{\prime} \mathrm{E}\right)$, both part of the municipal forest of the city of Brno, Czech
Republic. The long-term annual air temperature was $9.8^{\circ} \mathrm{C}$ (1987-2006), the long-term annual precipitation $533 \mathrm{~mm}$ (1994-2007). Four circular plots (177 m² each) were studied: two with coniferous trees only (Norwegian spruce, Scots pine, European larch), and two with mixed stands (pine, sessile oak, beech, black locust). One plot of each pair (stand type) was located within the game park, the other in the adjacent forest. The farthest distance between the plots was ca. $400 \mathrm{~m}$. The soil was partially Albeluvisol, partially mesotrophic Cambisol, with a silty loam texture, and the humus form moder, tending towards mor in the coniferous stands (Šídová \& Schlaghamerský, 2007) (Table 1).

Hrabeiella periglandulata was studied at this site from December 2003 to January 2007. From December 2003 to December 2004, six randomly positioned soil cores $\left(17 \mathrm{~cm}^{2}\right.$ area, depth mostly $12 \mathrm{~cm}$ or more) were taken at the beginning of each month, in each of the four above mentioned plots. Monthly sampling continued till November 2005 in one of the plots (mixed stand within the game park, with the highest density of $H$. periglandulata). In March and May 2006, and January 2007, further 6 or 8 cores per date were taken in this plot. All soil cores were cut into layers according to soil horizons $(3 \mathrm{~cm}$ layers, when horizons were thicker or not well distinguishable). All the subsamples were subjected to wet funnel extraction: 12-hour exposure without heating, then heating of the soil surface up to $43{ }^{\circ} \mathrm{C}$ within 3 hours. Extracted specimens were stored in water at $8{ }^{\circ} \mathrm{C}$ and, subsequently, counted under a binocular preparation microscope. During 2004, further soil samples were taken for analysis of soil chemistry and texture.

\section{Results and Discussion}

Except for a locality in southeastern Poland (Dumnicka \& Rożen, 2002), the study site presents

Table 1. Chemical soil characteristics of the study plots.

\begin{tabular}{|c|c|c|c|c|c|c|c|c|c|}
\hline Plot $^{(1)}$ & Soil layer $(\mathrm{cm})$ & $\mathrm{pH}\left(\mathrm{H}_{2} \mathrm{O}\right)$ & $\mathrm{pH}(\mathrm{KCl})$ & $P_{\text {total }}\left(\mathrm{mg} \mathrm{kg}^{-1}\right)$ & $\mathrm{C}_{\mathrm{ox}}\left(\mathrm{g} \mathrm{kg}^{-1}\right)$ & $\mathrm{N}\left(\mathrm{g} \mathrm{kg}^{-1}\right)$ & $\mathrm{Na}\left(\mathrm{mg} \mathrm{kg}^{-1}\right)$ & $\mathrm{K}\left(\mathrm{mg} \mathrm{kg}^{-1}\right)$ & $\mathrm{Ca}\left(\mathrm{mg} \mathrm{kg}^{-1}\right)$ \\
\hline $\mathrm{OC}$ & $0-3$ & 4.3 & 3.3 & 714 & 164 & 6 & 32 & 136 & 968 \\
\hline $\mathrm{OC}$ & $3-12$ & 3.9 & 3.1 & 266 & 34 & 2 & 70 & 20 & 82 \\
\hline OD & $0-3$ & 4.0 & 3.4 & 699 & 107 & 4 & 48 & 120 & 1024 \\
\hline OD & $3-12$ & 4.0 & 3.3 & 438 & 32 & 1 & 22 & 40 & 172 \\
\hline IC & $0-3$ & 4.0 & 3.3 & 983 & 233 & 10 & 24 & 180 & 1592 \\
\hline $\mathrm{IC}$ & $3-12$ & 3.9 & 3.2 & 563 & 56 & 4 & 80 & 52 & 258 \\
\hline ID & $0-3$ & 4.7 & 3.9 & 700 & 84 & 5 & 136 & 144 & 1504 \\
\hline ID & $3-12$ & 4.4 & 3.3 & 469 & 39 & 2 & 40 & 28 & 364 \\
\hline
\end{tabular}

${ }^{(1)} \mathrm{O}$, outside the Holedná Game Park; I, inside the game park; C, coniferous stand; D, mixed stand dominated by deciduous trees; $0-3 \mathrm{~cm}$ soil layer = organic layer, thickness variable; $3-12 \mathrm{~cm}$ soil layer = mineral layer, below organic layer (ca. $3 \mathrm{~cm}$ thick). 
the easternmost published record of the species, thus shifting the border of the known range further to the southeast, and by large closing the gap between known localities in the southwest, South Bohemia (Pižl \& Chalupský, 1984) and northwest (North Bohemia) of the Czech Republic, and the above mentioned Polish site (Figure 1). While the lack of records from most of Scandinavia, the Netherlands and the British Isles might represent a biological fact, the same is probably not true for further parts of western Europe, where a lack of soil mesofauna studies based on wet extraction techniques (usually used to study enchytraeids) might be responsible for missing records. The same is true for other parts of central, southern and eastern Europe, except for Austria and Hungary, where enchytraeids have been studied rather extensively, but $H$. periglandulata has not been recorded so far.

From December 2003 to December 2004, $H$. periglandulata was found in three of the four study plots: mixed forest stand inside Holedná Game Park (344 specimens); mixed forest stand outside Holedná Game Park (31 specimens); coniferous

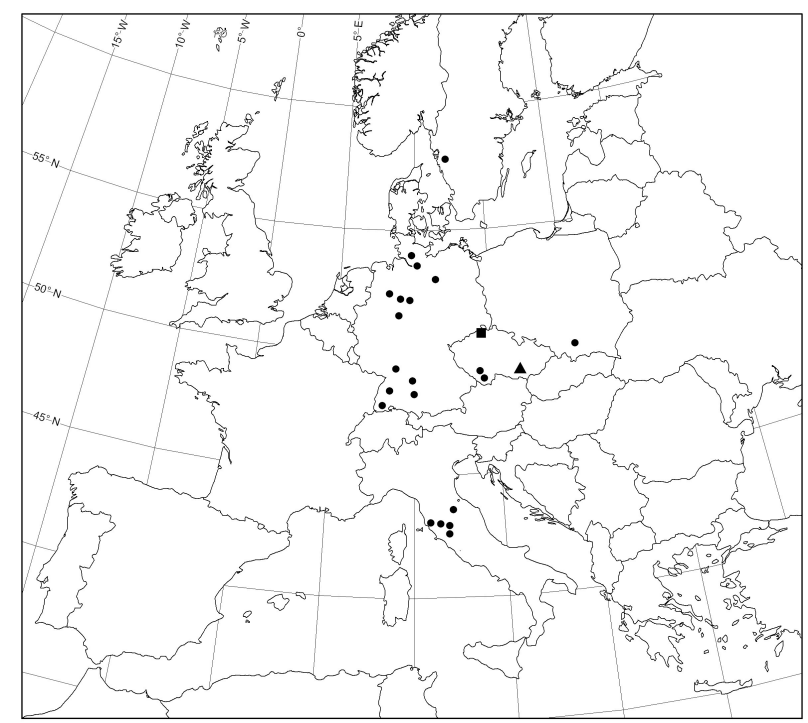

Figure 1. Records $(\bullet)$ of Hrabeiella periglandulata in Europe (Pižl \& Chalupský, 1984; Jans \& Römbke, 1989; Graefe, 1989, 1990, 1993a, 1993b; Rota \& Lupetti, 1996; Erséus \& Rota, 1998; Purschke, 1999; Dumnicka \& Rożen, 2002; Beylich \& Graefe, 2007; Šídová \& Schlaghamerský, 2007); ( \ ) our record from Brno, Czech Republic; ( $\mathbf{m}$ new record of first author from North Bohemia, Czech Republic (October 2008). forest stand inside Holedná Game Park (3 specimens). Densities differed substantially along a transect of only ca. $400 \mathrm{~m}$ (distance between the most remote plots). Over the entire study period until January 2007, 758 specimens were collected in the first plot (characterised by the highest soil $\mathrm{pH}$ ) (Table 1). The mean annual density, based on two years of monthly sampling, was 2,672 $\pm 1,534$ individuals $\mathrm{m}^{-2}$. The mean annual density of all enchytraeid species (based on one year of monthly sampling), in the first plot, was $14,500 \pm 4,900$ individuals $\mathrm{m}^{-2}$ (Š́dová \& Schlaghamerský, 2007). This shows that $H$. periglandulata can be a quantitatively important member of the annelid assemblage in soils (with individuals reaching up to $1.5 \mathrm{~mm}$ in body length, the biomass of an individual or of a given population will of course stay below that of most enchytraeid species). Annual density maxima were found in May 2004 and June 2005, and low densities from late summer till October or even into the winter as in December 2003 or November 2005 (Figure 2). The lowest mean density recorded in this plot was 196 individuals $\mathrm{m}^{-2}$ in September 2005, and the highest one was 11,863 individuals $\mathrm{m}^{-2}$ in June 2005. Due to the highly aggregated horizontal distribution (also indicated by the high standard errors of the mean), many of the monthly values did not differ significantly. However, the observed trend in population dynamics corresponded to the climatic development during the study period - with low densities at times of low precipitation and partially also low temperatures. This trend showed, particularly, the negative effect of the droughts at the end of the summer. The observed population dynamics differed from those at sites in southwestern Germany, where minima occurred in early summer, and maxima in winter (Jans \& Römbke, 1989). This is in rather good agreement with the differences between the more Atlantic climate in southwestern Germany and the more continental climate in southeastern Czech Republic, and shows that one has to be careful in drawing general conclusions on a species' biology based on local phenological data.

The studied population had a very even distribution in the upper soil profile down to ca. $15 \mathrm{~cm}$, only avoiding the organic layer (Figure 3). Particularly during the winter months (frozen soil), we were not always able to sample into greater depth than $9 \mathrm{~cm}$. To compensate for the underrepresented layers below this depth, the presented data for the individual layers have been weighted. The organic horizon in the study plots 


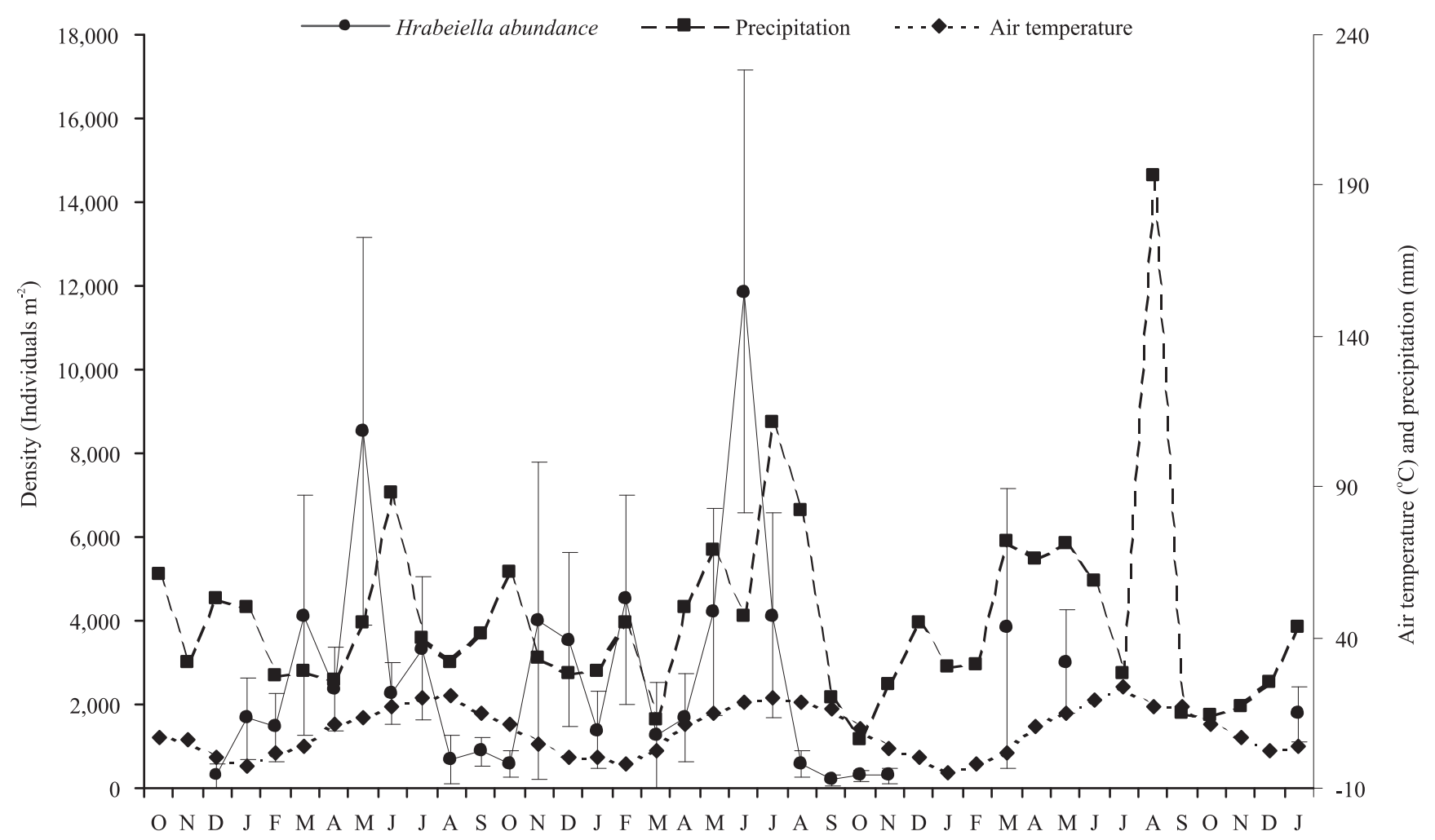

Figure 2. Population dynamics (mean monthly densities \pm SE) of Hrabeiella periglandulata in the most studied plot (mixed forest stand, inside Holedná Game Park) from December 2003 to January 2007; monthly mean air temperatures and precipitation sums from October 2003 to January 2007 from the closest meteorological station; note that abundance data were collected at the beginning of each month.

was often very dry during samplings. This might have contributed to the low percentage of $H$. periglandulata in this layer, as observed to some degree also in the case of enchytraeids (Schlaghamerský \& Šídová, 2007; Šídová $\&$ Schlaghamerský, 2007). However, avoidance of the uppermost organic soil layer by $H$. periglandulata was also observed elsewhere within its known range (Jans \& Römbke, 1989; Graefe \& Schmelz, 1999). The high percentage of specimens found in the sampled part of the B-horizon at our site (depending on the soil core these were $12-15 \mathrm{~cm}$ and, partially, also 9-12 cm layers) was remarkable, as this consisted of very fine, silty mineral soil with very little organic matter. Thus, although the soil at our site seemed rather special, the vertical distribution of $H$. periglandulata found here was in agreement with that observed by other authors (Jans \& Römbke, 1989; Graefe \& Schmelz, 1999). It is possible that the proportions of

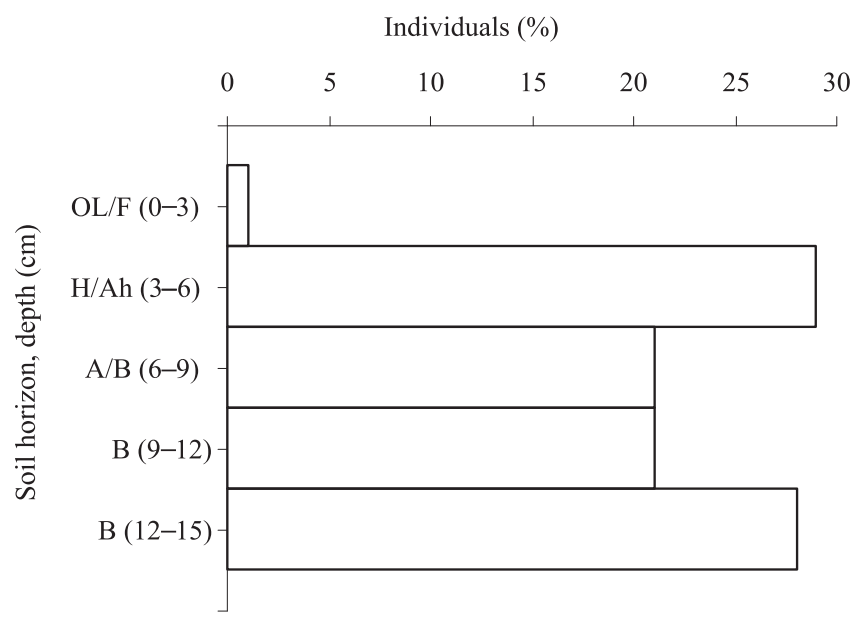

Figure 3. Vertical distribution (mean percentages of individuals present in individual soil layers) of Hrabeiella periglandulata in the most studied plot (mixed forest stand, inside Holedná Game Park). 
individuals dwelling in greater depths than the sampled ones were not negligible, and the true population densities might be, therefore, higher than those presented.

\section{Conclusions}

1. Hrabeiella periglandulata can reach densities of several thousand individuals per square metre, comparable to the densities of other small soil annelids - in particular enchytraeids - in the same soils.

2. The population of $H$. periglandulata in Brno reaches maximal densities in late spring to early summer and minimal densities in late summer to autumn.

3. At the study site, $H$. periglandulata is rather evenly distributed in the upper $15 \mathrm{~cm}$ of soil, only avoiding the litter layer.

4. The range of $H$. periglandulata reaches further to the southeast than previously reported.

\section{Acknowledgements}

To the Ministry of Education, Youth and Sports of the Czech Republic for funding the Masaryk University's research plan MSM 0021622416.

\section{References}

BEYLICH, A.; GRAEFE, U. Investigations on the enchytraeid fauna in floodplain soils of the Lower Middle Elbe. Folia Facultatis Scientiarum Naturalium Universitatis Masarykianae Brunensis, Biologia, v.110, p.107-122, 2007.

DUMNICKA, E.; ROŻEN, A. The first record of the terrestrial polychaete Hrabeiella periglandulata Pižl et Chalupský, 1984, in Poland, with a note on anatomy and ecology. Fragmenta Faunistica, v.45, p.1-7, 2002.

ERSÉUS, C.; ROTA, E. Polychaetes (bristle worms) on dry land. Fauna och Flora, v.93, p.97-104, 1998.

GRAEFE, U. Der Einfluß von sauren Niederschlägen und Bestandeskalkungen auf die Enchytraeidenfauna in Waldböden. Verhandlungen der Gesellschaft für Ökologie, v.17, p.597-603, 1989.

GRAEFE, U. Die Gliederung von Zersetzergesellschaften für die standortsökologische Ansprache. Mitteilungen der Deutschen Bodenkundlichen Gesellschaft, v.69, p.95-98, 1993a.

GRAEFE, U. Untersuchungen zum Einfluß von Kompensationskalkung und Bodenbearbeitung auf die Zersetzerfauna in einem bodensauren Buchenwald und Fichtenforst-Ökosystem. In: GEHRMANN, J. (Ed.). Umweltkontrolle am Waldökosystem. Münster: Forschung und Beratung, Reihe C, 1990. v.48, p.232-241.

GRAEFE, U. Veränderungen der Zersetzergesellschaften im Immissionsbereich eines Zementwerkes. Mitteilungen der Deutschen Bodenkundlichen Gesellschaft, v.72, p.531-534, $1993 \mathrm{~b}$.
GRAEFE, U.; SCHMELZ, R.M. Indicator values, strategy types and life forms of terrestrial Enchytraeidae and other microannelids. In: SCHMELZ, R.M.; SÜHLO, K. (Ed.). Newsletter on Enchytraeidae No. 6: proceedings of the 3rd International Symposium on Enchytraeidae, Osnabrück, Germany, 3-4 July 1998. Osnabrück: Universitätsverlag Rasch, 1999. p.59-67.

JANS, W.; RÖMBKE, J. Funde eines terrestrischen Polychaeten (Annelida) in Wäldern Baden-Württembergs. Carolinea, v.47, p.158-162, 1989.

JÖRDENS, J.; STRUCK, T.; PURSCHKE, G. Phylogenetic inference regarding Parergodrilidae and Hrabeiella periglandulata ('Polychaeta', Annelida) based on 18S rDNA, 28S rDNA and COI sequences. Journal of Zoological Systematics and Evolutionary Research, v.42, p.270-280, 2004.

PIŽL, V.; CHALUPSKÝ, J. Hrabeiella periglandulata gen. et sp. n. (Annelida) - a curious worm from Czechoslovakia. Věstník československé Společnosti zoologické, v.48, p.291-295, 1984.

PURSCHKE, G. Is Hrabeiella periglandulata (Annelida, 'Polychaeta') the sister group of Clitellata? Evidence from an ultrastructural analysis of the dorsal pharynx in $H$. periglandulata and Enchytraeus minutus (Annelida, Clitellata). Zoomorphology, v.122, p.55-66, 2003.

PURSCHKE, G. Sense organs and central nervous system in an enigmatic terrestrial polychaete, Hrabeiella periglandulata (Annelida) -implications for annelid evolution. Invertebrate Biology, v.119, p.329-341, 2000.

PURSCHKE, G. Terrestrial polychaetes - models for the evolution of the Clitellata (Annelida)? Hydrobiologia, v.406, p.87-99, 1999.

ROTA, E. Morphology and adaptations of Parergodrilus Reisinger and Hrabeiella Pizl \& Chalupský, two enigmatic soil-dwelling annelids. Italian Journal of Zoology, v.65, p.75-84, 1998.

ROTA, E.; LUPETTI, P. An ultrastructural investigation of Hrabeiella Pizl \& Chalupský, 1984 (Annelida). I. Chaetae and body wall organization. Hydrobiologia, v.334, p.229-239, 1996.

ROTA, E.; LUPETTI, P. An ultrastructural investigation of Hrabeiella Pizl \& Chalupský, 1984 (Annelida). II. The spermatozoon. Tissue \& Cell, v.29, p.603-609, 1997.

ROTA, E.; MARTIN, P.; ERSÉUS, C. Soil-dwelling polychaetes: enigmatic as ever? Some hints on their phylogenetic relationships as suggested by a maximum parsimony analysis of $18 \mathrm{~S}$ rRNA gene sequences. Contributions to Zoology, v.70, p.127-138, 2001.

SCHLAGHAMERSKÝ, J.; ŠÍDOVÁ, A. On a species-poor enchytraeid community of peculiar composition. Folia Facultatis Scientiarum Naturalium Universitatis Masarykianae Brunensis, Biologia, v.110, p.183-192, 2007.

ŠÍDOVÁ, A.; SCHLAGHAMERSKÝ, J. The impact of high game density on enchytraeids in a mixed forest. In: TAJOVSKÝ, K.; SCHLAGHAMERSKÝ, J.; PIŽL, V. Contributions to soil zoology in Central Europe II. České Budějovice: Institute of Soil Biology, Biology Centre, Academy of Sciences of the Czech Republic, 2007. p.147-152. 